\title{
Social determinants of health and COVID-19 infection in Brazil: an analysis of the pandemic
}

\author{
Determinantes sociais da saúde e infecção por COVID-19 no Brasil: uma análise da epidemia \\ Determinantes sociales de la salud y la infección por COVID-19 en Brasil: un análisis de la pandemia
}

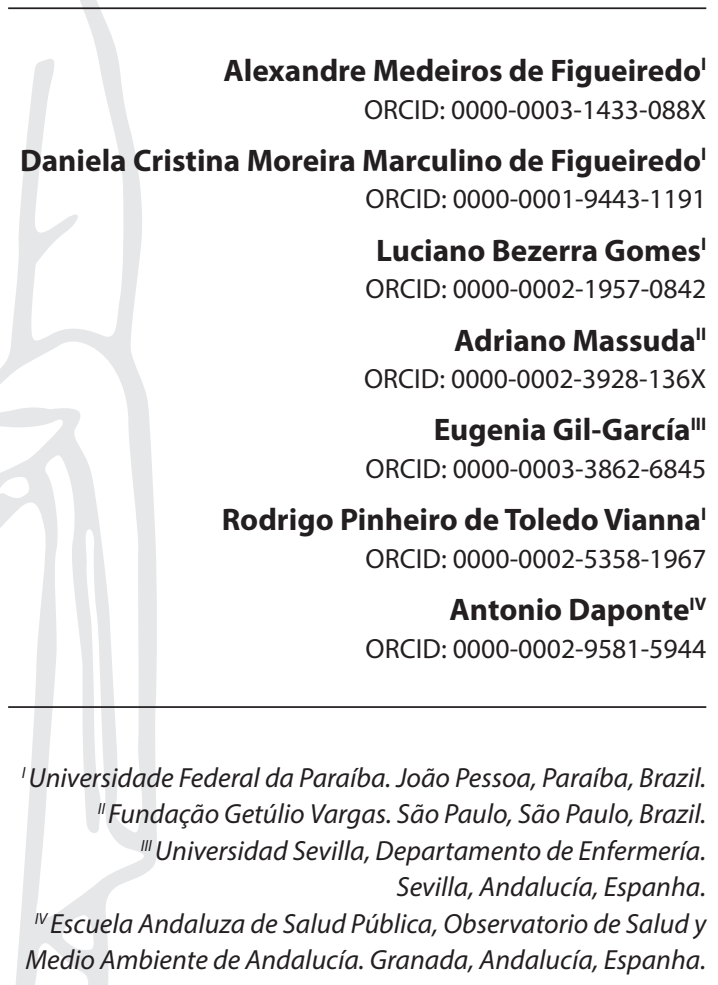

How to cite this article:

Figueiredo AM, Figueiredo DCMM, Gomes LB, Massuda A,

Gil-García E, Vianna RPT, et al. Social determinants of health and COVID-19 infection in Brazil: an analysis of the pandemic. Rev Bras Enferm. 2020;73(Suppl 2):e20200673. doi: http://dx.doi.org/10.1590/0034-7167-2020-0673

Corresponding author:

Alexandre Medeiros de Figueiredo

E-mail: potiguar77@gmail.com

EDITOR IN CHIEF: Dulce Barbosa ASSOCIATE EDITOR: Álvaro Sousa

\section{ABSTRACT}

Objective: To analyze the influence of socioeconomic, demographic, epidemiological factors, and the health system structure in the evolution of the COVID-19 pandemic in Brazil. Methods: Ecological study with variables extracted from databases, having the incidence and mortality by COVID-19 until August 23, 2020, in Brazilian states, as response variables. The magnitude of the associations was estimated using Spearman's correlation coefficient and multiple regression analysis. Results: In the Brazilian states, $59.8 \%$ of variation in the incidence of COVID-19 was justified by income inequality, significant home densification, and higher mortality. In the case of mortality, those same variables explained $57.9 \%$ of the country's variations in federal units. Conclusion: Our results indicate that socioeconomic factors influenced the evolution and impact of COVID-19 in Brazil. Thus, we suggest comprehensive actions to ensure economic conditions and strengthening of health networks for populations with socioeconomic vulnerability.

Descriptors: Social Determinants of Health; Epidemiology; Infections; Coronavirus infection; Epidemics.

\section{RESUMO}

Objetivo: Analisar a influência de fatores socioeconômicos, demográficos, epidemiológicos e da estrutura do sistema de saúde na evolução da pandemia da COVID-19 no Brasil. Métodos: Estudo ecológico com variáveis extraídas de bancos de dados, tendo a incidência e mortalidade por COVID 19 até 23 de agosto de 2020, nos estados brasileiros, como variáveis-resposta. A magnitude das associações foi estimada usando o coeficiente de correlação de Spearman e análise de regressão múltipla. Resultados: Nos estados brasileiros, $59,8 \%$ da variação da incidência de COVID-19 foi justificada pela desigualdade de renda, maior adensamento domiciliar e maior letalidade. No caso da mortalidade, essas mesmas variáveis explicaram $57,9 \%$ das variações encontradas nas Unidades Federativas do país. Conclusão: Nossos resultados indicam que fatores socioeconômicos influenciaram a evolução e impacto da COVID-19 no Brasil. Dessa forma, sugerimos ações abrangentes a fim de garantir condições econômicas e o fortalecimento das redes de saúde para populações com vulnerabilidade socioeconômica.

Descritores: Determinantes Sociais da Saúde; Epidemiologia; Infecções; Infecções por Coronavírus; Epidemias.

\section{RESUMEN}

Objetivo: Analizar la influencia de factores socioeconómicos, demográficos, epidemiológicos y estructura del sistema de salud en la evolución del COVID-19 en Brasil. Métodos: Estudio ecológico con variables extraídas de bancos de datos, teniendo la incidencia y mortalidad por COVID-19 hasta 23 de agosto de 2020, en estados brasileños, como variables respuesta. Las relaciones han estimadas usando el coeficiente de correlación de Spearman y análisis de regresión múltiple. Resultados: En los estados brasileños, 59,8\% de la variación de la incidencia de COVID-19 ha justificada por la desigualdad de renta, mayor densificación domiciliar y mayor letalidad. En la mortalidad, esas mismas variables explicaron $57,9 \%$ de las variaciones encontradas en las Unidades Federativas del país. Conclusión: Nuestros resultados indican que factores socioeconómicos influenciaron la evolución e impacto de COVID-19 en Brasil. Así, sugerimos acciones abarcadoras para garantizar condiciones económicas y el fortalecimiento de las redes de salud para poblaciones con vulnerabilidad socioeconómica. Descriptores: Determinantes Sociales de la Salud, Epidemiología; Infecciones; Infecciones por Coronavirus; Epidemias. 


\section{INTRODUCTION}

The coronavirus of severe acute respiratory syndrome 2 (SARS-CoV-2) is transmitted mainly through contact with secretions and respiratory system fluids, both through droplets and aerosols and by contact with contaminated surfaces ${ }^{(1)}$. The transmissibility of SARS-CoV-2 is high, with $\mathrm{R} O$ (basic reproduction number) ranging in early pandemic studies from $2.68(95 \% \mathrm{Cl} 2.47-2.86)^{(2)}$ to $5.7(95 \% \mathrm{Cl} 3.8-8.9)^{(3)}$.

Despite promising research and advances, there is no vaccine or specific pharmacological treatment available, making individual prevention measures and social distancing essential to avoid increasing the number of cases and deaths ${ }^{(4)}$. These measures are recommended by the World Health Organization (WHO), and each country use them in varying degrees of intensity, according to its reality ${ }^{(5)}$. Recently, studies have demonstrated that such actions have been able to reduce the number of cases and deaths by COVID-19(6).

Like other diseases, the social determinants of health are likely to influence the risk of infection, morbidity, and mortality associated with COVID-19(7). However, few studies have evaluated the association of the evolution and impact of the pandemic by COVID-19 with socioeconomic factors ${ }^{(7)}$. These factors may be particularly important in countries like Brazil, characterized by social inequality, where large population contingents live below the poverty line and in housing without basic sanitation ${ }^{(8)}$. Furthermore, there are regional inequities of access to health care that add to these inequalities, because there are concentration of intensive care unit (ICU) beds and professionals in health regions with better socioeconomic indicators ${ }^{(9)}$. The aggravation of this scenario happens due to the reduction of funding from the Unified Health System (SUS) generated by the constitutional amendment that limited federal health expenditures for 20 years ${ }^{(10)}$.

\section{OBJECTIVE}

Analyze the influence of socioeconomic, demographic, epidemiological factors, and the health system structure in the evolution of the COVID-19 pandemic in Brazil.

\section{METHODS}

\section{Ethical Aspects}

The study used secondary public domain data that do not identify participants. Therefore, the approval of the Ethics Committee was not mandatory.

\section{Design, period, and location of study}

Ecological study, guided by the STROBE ${ }^{(11)}$ tool, based on secondary data from the Brazilian Ministry of Health regarding the number of confirmed cases and deaths by COVID-19 until August 23, 2020(12).

\section{Population and inclusion criteria}

The study included data related to socioeconomic, demographic, epidemiological factors, and the health structure of all
Brazilian Federative Units (FU), which was the unit of aggregation for analysis.

\section{Protocol of study}

The incidence and mortality rates were used as the response variable to the pandemic's evolution, so they analyzed the outcomes. Incidence and mortality rates per 100,000 inhabitants were calculated according to the total cases and deaths confirmed by COVID-19 ${ }^{(12)}$ and data from the population projections of the Brazilian Institute of Geography and Statistics (IBGE) for the year $2019^{(13)}$.

It was used independent variables of four dimensions: epidemiological, demographic, health system structure, and socioeconomic. The pandemic time was calculated considering the period between the first notification date in each FU and August 23, 2020. The lethality rate was calculated through the relationship between deaths and cases confirmed by COVID-19. Prevalence of smoking, hypertension, diabetes, and overweight people (BMI $>25 \mathrm{~kg} / \mathrm{m} 2$ ) were extracted from the 2019 VIGITEL survey, considering the prevalence of the state capital as a parameter for each $\mathrm{FU}^{(14)}$. These conditions were chosen due to studies suggesting such factors as associated with morbidity and mortality by COVID-19(15-16) . The proportion of people over 60 years of age was calculated according to the National Quarterly Continuous Household Survey estimates in the fourth quarter of 2019(17) and the IBGE population projections for $2019^{(13)}$. The number of physicians was extracted from the base of the National Registry of Health Establishments, including physicians linked and not linked to the SUS ${ }^{(18)}$, and the number of ICU beds was based on data made available at the Strategic Management Support Room of the Ministry of Health for May 2020(19).

Socioeconomic variables such as the Gini Index of household income per capita, unemployment rate, percentage of uneducated population and percentage of people living with household income per capita in dollars below the poverty line, access to water and sewage systems, and overcrowding (households with three or more inhabitants per dormitory) were extracted from the tables of the 2019 Synthesis of Social Indicators (SSI) of the IBGE, with data referring to the year 2018 ${ }^{(20)}$. Data on Gross Domestic Product (GDP) were extracted from the tables made available by $\mathrm{IBGE}^{(21)}$. The per capita value was obtained from the values of the GDP of 2017 and the population in each FU.

\section{Analysis of results and statistics}

To identify and estimate the magnitude of the association between the independent variables and the response variables, it was performed the Spearman's correlation analysis. The independent variables that did not show predictive power under the dependent variable were then excluded, maintaining in the models the independent variables with significant results in the correlation analysis. Afterward, it was performed a multiple linear regression analysis, with separate models for incidence and mortality, to verify whether the independent variables could explain or predict the dependent variable. In order to meet the assumptions of data normality and homogeneity, the incidence rates were transformed logarithmically. 
$\Upsilon\left(\log _{\text {incidência }}\right)=\beta_{0}+\beta_{1} \chi_{1}+\beta_{2} \chi_{2}+\ldots+\beta \mathrm{k} \chi \mathrm{k}+u_{\mathrm{i}}$

$\Upsilon\left(\log _{\text {mortalidade }}\right)=\beta_{0}+\beta_{1} \chi_{1}+\beta_{2} \chi_{2}+\ldots+\beta \mathrm{k} \chi \mathrm{k}+u_{\mathrm{i}}$

$\Upsilon$ refers to the predicted value of the dependent variable (incidence or mortality), transformed into logarithm, $\beta_{0}$ represents the constant (intercept), $\beta \mathrm{n}$ is the coefficient of each independent variable $(n=1,2, \ldots k), x_{n}$ deals with each independent variable ( $n=1,2, \ldots k$ ), where $k$ is the number of independent variables, and $u$ is the error or surplus.

It was obtained the adjustment of each model and the analysis of variance (ANOVA). The independent variables were analyzed for their relevance in the model using the $t$-test with significance of $p<0.05$. The independencies of the residues were also analyzed using the Durbin Watson test (DW $>1.5$ ) and the collinearity test (Tolerance $>0.1$ and Variance Inflation Factor [VIF] < 10). The data were processed and analyzed using the Statistical Package for Social Sciences (SPSS), version 20.0.

\section{RESULTS}

Since the beginning of the pandemic, the time varied from 151 days in Roraima to 176 days in São Paulo, being 16.6\% higher in this state. Incidence rates varied considerably among FU, as shown in Table 1. The lowest incidence was 919.3 cases per 100,000 inhabitants in Minas Gerais, and the highest in Roraima, with $6,688.9$ cases per 100,000 inhabitants, which is 7.29 times higher. The lowest mortality was 22.6 deaths per 100,000 inhabitants in Minas Gerais, and the highest mortality was in Roraima, with 95.6 deaths per 100,000 inhabitants. The average mortality rate in Brazil was $2.77 \%$, ranging from $1.34 \%$ in the Tocantins to $7.3 \%$ in Rio de Janeiro, a value 5.4 times higher.

Table 2 presents the prevalence related to chronic conditions, habits, and housing conditions. It is possible to observe variation among FUs, especially in relation to housing conditions.

Table 1 - Epidemiological and structure variables of the Health System per Federative Unit, Brazil, 2020

\begin{tabular}{|c|c|c|c|c|c|c|c|}
\hline Federative Unit & $\begin{array}{l}\text { Period of } \\
\text { pandemic }\end{array}$ & $\begin{array}{l}\text { Incidence per } \\
100,000 \text { people }\end{array}$ & $\begin{array}{l}\text { Mortality per } \\
100,000 \text { people }\end{array}$ & $\begin{array}{c}\text { Lethality } \\
\text { Rate } \\
(\%)\end{array}$ & $\begin{array}{l}\text { People over } \\
60 \text { years (\%) }\end{array}$ & $\begin{array}{l}\text { ICU Adult beds } \\
\text { per } 10,000 \\
\text { people }\end{array}$ & $\begin{array}{l}\text { Physician per } \\
100,000 \text { people }\end{array}$ \\
\hline Acre & 154 & 2689.43 & 68.03 & 2.53 & 11.00 & 0.66 & 1.10 \\
\hline Alagoas & 165 & 2272.97 & 54.47 & 2.40 & 15.00 & 1.28 & 1.32 \\
\hline Amapá & 153 & 4862.07 & 74.61 & 1.53 & 9.00 & 0.92 & 0.98 \\
\hline Amazonas & 158 & 2789.54 & 85.97 & 3.08 & 9.00 & 1.09 & 1.12 \\
\hline Bahia & 167 & 1587.10 & 32.98 & 2.08 & 16.00 & 1.05 & 1.36 \\
\hline Ceará & 156 & 2249.66 & 90.77 & 4.03 & 16.00 & 1.10 & 1.27 \\
\hline Distrito Federal & 166 & 4941.45 & 75.42 & 1.53 & 13.00 & 3.31 & 3.44 \\
\hline Espírito Santo & 167 & 2635.01 & 75.30 & 2.86 & 16.00 & 2.00 & 2.21 \\
\hline Goiás & 160 & 1662.27 & 39.08 & 2.35 & 14.00 & 1.71 & 1.73 \\
\hline Maranhão & 152 & 2040.94 & 47.38 & 2.32 & 13.00 & 0.96 & 0.82 \\
\hline Mato Grosso & 153 & 2331.86 & 72.46 & 3.11 & 12.00 & 1.70 & 1.53 \\
\hline Mato Grosso do Sul & 157 & 1529.26 & 26.56 & 1.74 & 14.00 & 1.52 & 2.00 \\
\hline Minas Gerais & 165 & 919.34 & 22.63 & 2.46 & 17.00 & 1.49 & 2.24 \\
\hline Pará & 154 & 2200.30 & 70.41 & 3.20 & 12.00 & 0.77 & 0.85 \\
\hline Paraíba & 154 & 2516.89 & 57.44 & 2.28 & 16.00 & 1.33 & 1.55 \\
\hline Paraná & 161 & 1031.66 & 26.04 & 2.52 & 16.00 & 1.78 & 2.14 \\
\hline Pernambuco & 161 & 1246.62 & 77.32 & 6.20 & 16.00 & 1.72 & 1.54 \\
\hline Piauí & 153 & 2196.27 & 52.36 & 2.38 & 16.00 & 0.90 & 1.24 \\
\hline Rio de Janeiro & 168 & 1221.83 & 88.57 & 7.25 & 21.00 & 2.33 & 2.40 \\
\hline Rio grande do Norte & 160 & 1699.02 & 61.88 & 3.64 & 16.00 & 1.50 & 1.49 \\
\hline Rio grande do Sul & 163 & 965.73 & 26.91 & 2.79 & 20.00 & 1.46 & 2.47 \\
\hline Rondônia & 153 & 2893.33 & 59.92 & 2.07 & 12.00 & 1.60 & 1.44 \\
\hline Roraima & 151 & 6888.86 & 95.58 & 1.39 & 7.00 & 0.41 & 1.46 \\
\hline Santa Catarina & 160 & 1849.21 & 28.50 & 1.54 & 16.00 & 1.49 & 2.25 \\
\hline São Paulo & 176 & 1642.30 & 61.99 & 3.77 & 17.00 & 2.02 & 2.58 \\
\hline Sergipe & 158 & 3065.74 & 77.52 & 2.53 & 12.00 & 1.28 & 1.63 \\
\hline Tocantins & 154 & 2771.76 & 37.19 & 1.34 & 14.00 & 1.02 & 1.48 \\
\hline
\end{tabular}

Table 2 - Prevalence of chronic conditions, living habits and living conditions per Federative Unit, Brazil, 2020

\begin{tabular}{|c|c|c|c|c|c|c|c|}
\hline Federative Unit & $\begin{array}{l}\text { Prevalence of } \\
\text { smoking (\%) }\end{array}$ & $\begin{array}{c}\text { Prevalence of } \\
\text { hipertension (\%) }\end{array}$ & $\begin{array}{l}\text { Prevalence of } \\
\text { diabetes (\%) }\end{array}$ & $\begin{array}{l}\text { Overweight } \\
\text { people }\end{array}$ & $\begin{array}{c}\text { People with } \\
\text { no access to } \\
\text { general water } \\
\text { supply }\end{array}$ & $\begin{array}{c}\text { People with no } \\
\text { access to sewage } \\
\text { network }\end{array}$ & $\begin{array}{c}\text { People in } \\
\text { overcrowdedhouseholds }\end{array}$ \\
\hline Acre & 11.90 & 18.50 & 4.90 & 56.60 & 45.90 & 64.54 & 12.76 \\
\hline Alagoas & 5.50 & 26.80 & 8.20 & 54.40 & 22.81 & 58.20 & 6.95 \\
\hline Amapá & 7.30 & 23.30 & 5.20 & 53.30 & 40.94 & 85.70 & 24.02 \\
\hline Amazonas & 5.20 & 18.40 & 6.00 & 60.90 & 28.16 & 68.61 & 22.41 \\
\hline Bahia & 5.40 & 25.20 & 6.70 & 51.80 & 16.07 & 44.53 & 5.18 \\
\hline Ceará & 7.90 & 21.20 & 7.40 & 55.60 & 21.30 & 58.17 & 7.42 \\
\hline Distrito Federal & 12.00 & 28.50 & 7.70 & 55.00 & 5.00 & 13.55 & 4.87 \\
\hline Espírito Santo & 7.50 & 24.30 & 6.40 & 49.10 & 14.37 & 21.83 & 4.99 \\
\hline Goiás & 8.70 & 24.30 & 6.60 & 52.70 & 12.29 & 46.02 & 4.07 \\
\hline Maranhão & 4.80 & 16.90 & 6.40 & 50.30 & 29.96 & 78.49 & 12.25 \\
\hline
\end{tabular}




\begin{tabular}{|c|c|c|c|c|c|c|c|}
\hline Federative Unit & $\begin{array}{l}\text { Prevalence of } \\
\text { smoking (\%) }\end{array}$ & $\begin{array}{c}\text { Prevalence of } \\
\text { hipertension (\%) }\end{array}$ & $\begin{array}{l}\text { Prevalence of } \\
\text { diabetes (\%) }\end{array}$ & $\begin{array}{l}\text { Overweight } \\
\text { people }\end{array}$ & $\begin{array}{c}\text { People with } \\
\text { no access to } \\
\text { general water } \\
\text { supply }\end{array}$ & $\begin{array}{c}\text { People with no } \\
\text { access to sewage } \\
\text { network }\end{array}$ & $\begin{array}{c}\text { People in } \\
\text { overcrowdedhouseholds }\end{array}$ \\
\hline Mato Grosso & 7.90 & 22.80 & 7.00 & 55.80 & 20.01 & 66.30 & 5.85 \\
\hline Mato Grosso do Sul & 10.30 & 24.90 & 5.90 & 58.00 & 11.92 & 52.33 & 4.58 \\
\hline Minas Gerais & 8.20 & 25.80 & 8.00 & 52.50 & 11.33 & 18.56 & 2.71 \\
\hline Pará & 6.60 & 19.30 & 6.80 & 53.30 & 50.39 & 85.71 & 14.11 \\
\hline Paraíba & 6.80 & 25.60 & 6.80 & 54.70 & 24.05 & 50.77 & 5.27 \\
\hline Paraná & 11.30 & 21.10 & 7.00 & 53.70 & 9.75 & 30.79 & 3.14 \\
\hline Pernambuco & 7.90 & 28.40 & 8.10 & 59.50 & 23.90 & 45.19 & 5.98 \\
\hline Piauí & 4.40 & 22.40 & 6.30 & 52.70 & 14.92 & 92.98 & 6.39 \\
\hline Rio de Janeiro & 10.10 & 28.00 & 8.30 & 57.10 & 11.26 & 12.09 & 8.64 \\
\hline Rio grande do Norte & 7.60 & 24.50 & 7.30 & 56.60 & 14.88 & 76.83 & 7.39 \\
\hline Rio grande do Sul & 14.60 & 28.20 & 8.60 & 59.20 & 10.18 & 30.71 & 3.49 \\
\hline Rondônia & 8.00 & 19.60 & 4.60 & 56.60 & 58.01 & 90.59 & 5.29 \\
\hline Roraima & 7.20 & 20.40 & 7.00 & 54.30 & 13.11 & 60.09 & 17.84 \\
\hline Santa Catarina & 10.70 & 21.60 & 6.10 & 53.60 & 16.46 & 43.53 & 1.99 \\
\hline São Paulo & 13.50 & 24.40 & 7.90 & 55.80 & 4.17 & 7.71 & 7.74 \\
\hline Sergipe & 4.70 & 25.10 & 7.30 & 51.80 & 13.80 & 46.83 & 5.33 \\
\hline Tocantins & 7.00 & 17.60 & 4.70 & 49.90 & 18.55 & 70.05 & 6.70 \\
\hline
\end{tabular}

Table 3 - Economic Indicators per Federative Unit, Brazil, 2020

\begin{tabular}{|c|c|c|c|c|c|c|c|}
\hline Federative Unit & $\begin{array}{c}\text { Gini } \\
\text { Index }\end{array}$ & $\begin{array}{l}\text { Population average } \\
\text { monthly income } \\
\text { (R\$) }\end{array}$ & $\begin{array}{l}\text { GDP per capita } \\
\text { (R\$) }\end{array}$ & $\begin{array}{l}\text { Vacancy } \\
\text { rate }(\%)\end{array}$ & $\begin{array}{l}\text { Below } \\
\text { the poverty } \\
\text { line }\end{array}$ & $\begin{array}{l}\text { Below the } \\
\text { extreme } \\
\text { poverty line }\end{array}$ & $\begin{array}{l}\text { People without } \\
\text { education (\%) }\end{array}$ \\
\hline Acre & 0.56 & $1,715.00$ & $16,180.00$ & 13.20 & 23.89 & 14.38 & 13.22 \\
\hline Alagoas & 0.55 & $1,348.00$ & $15,830.00$ & 16.33 & 29.60 & 17.23 & 16.91 \\
\hline Amapá & 0.55 & $1,667.00$ & $18,300.00$ & 20.54 & 24.76 & 9.79 & 7.75 \\
\hline Amazonas & 0.55 & $1,651.00$ & $22,490.00$ & 13.79 & 25.18 & 13.78 & 7.68 \\
\hline Bahia & 0.55 & $1,504.00$ & $18,060.00$ & 16.43 & 22.98 & 12.95 & 14.55 \\
\hline Ceará & 0.55 & $1,561.00$ & $16,190.00$ & 11.49 & 23.07 & 12.49 & 13.42 \\
\hline Distrito Federal & 0.57 & $4,189.00$ & $81,150.00$ & 12.24 & 5.33 & 3.11 & 4.22 \\
\hline Espírito Santo & 0.51 & $2,265.00$ & $28,210.00$ & 10.93 & 8.03 & 3.97 & 6.09 \\
\hline Goiás & 0.47 & $2,015.00$ & $27,340.00$ & 9.10 & 6.23 & 3.10 & 6.81 \\
\hline Maranhão & 0.53 & $1,223.00$ & $12,650.00$ & 14.36 & 31.85 & 19.93 & 16.73 \\
\hline Mato Grosso & 0.46 & $2,152.00$ & $36,390.00$ & 7.72 & 4.95 & 2.39 & 8.11 \\
\hline Mato Grosso do Sul & 0.49 & $2,352.00$ & $34,680.00$ & 7.95 & 6.22 & 2.95 & 5.25 \\
\hline Minas Gerais & 0.49 & $2,040.00$ & $27,220.00$ & 10.67 & 7.28 & 3.52 & 4.93 \\
\hline Pará & 0.56 & $1,446.00$ & $18,040.00$ & 11.57 & 23.71 & 11.81 & 7.92 \\
\hline Paraíba & 0.55 & $1,529.00$ & $15,530.00$ & 10.31 & 22.36 & 11.24 & 14.17 \\
\hline Paraná & 0.49 & $2,428.00$ & $36,850.00$ & 8.23 & 5.32 & 2.71 & 5.94 \\
\hline Pernambuco & 0.53 & $1,630.00$ & $19,000.00$ & 16.08 & 22.68 & 11.41 & 11.03 \\
\hline Piauí & 0.53 & $1,385.00$ & $13,860.00$ & 12.58 & 24.61 & 14.15 & 13.04 \\
\hline Rio de Janeiro & 0.54 & $2,822.00$ & $38,890.00$ & 14.70 & 7.62 & 3.80 & 3.62 \\
\hline Rio grande do Norte & 0.54 & $1,758.00$ & $18,330.00$ & 12.77 & 20.72 & 10.31 & 8.00 \\
\hline Rio grande do Sul & 0.49 & $2,586.00$ & $37,190.00$ & 8.26 & 5.12 & 1.93 & 2.70 \\
\hline Rondônia & 0.50 & $1,883.00$ & $24,480.00$ & 9.23 & 10.15 & 4.71 & 8.50 \\
\hline Roraima & 0.57 & $2,063.00$ & $19,980.00$ & 12.79 & 17.42 & 8.43 & 7.72 \\
\hline Santa Catarina & 0.42 & $2,466.00$ & $38,690.00$ & 6.29 & 2.92 & 1.44 & 3.18 \\
\hline São Paulo & 0.54 & $2,891.00$ & $46,170.00$ & 12.99 & 5.61 & 2.75 & 3.11 \\
\hline Sergipe & 0.58 & $1,605.00$ & $17,710.00$ & 16.26 & 24.66 & 13.92 & 12.12 \\
\hline Tocantins & 0.53 & $1,736.00$ & $21,680.00$ & 10.84 & 14.44 & 6.59 & 12.94 \\
\hline
\end{tabular}

The variables related to the economy in the FUs are presented in Table 3. It should be noted that the proportion of people below the extreme poverty line varied between $1.44 \%$ in Santa Catarina and $19.93 \%$ in Maranhão.

The correlation of the pandemic time was positive with the number of physicians per thousand inhabitants $(r=0.685 ; p<$ $0.01)$, number of beds per 10 thousand inhabitants $(r=0.635 ; p<$ $0.01)$ and GDP per capita $(r=0.512 ; p<0.01)$ in the FU. The time of pandemic evolution presented a negative correlation with the proportion of people living in households without access to sewage $(r=-0.827 ; p<0.01)$ and water $(r=-0.569 ; p<0.01)$, with the percentage of people without education $(r=-0.420 ; p<0.05)$ and below the FU poverty line $(r=-0.409 ; p<0.05)$.
The incidence rates presented a moderate correlation with overcrowding $(r=0.562 ; p<0.01)$ and with the Gini Index $(r=$ $0.471 ; p<0.05$ ). A negative correlation was observed between incidence and the percentage of people over 60 years old $(r=$ $-0.755 ; p<0.01)$, lethality rate $(r=-0.445 ; p<0.05)$ and time of the pandemic beginning in the $\mathrm{FU}(r=-0.387 ; p<0.05)$. Mortality rates correlated with the Gini Index $(r=0.605 ; p<0.01)$, overcrowding $(r=0.556 ; p<0.01)$, vacancy rate $(r=0.459 ; p<0.05)$, lethality rate $(r=0.408 ; p<0.05)$.

The regression model, considering as a dependent variable the incidence of COVID-19 included three independent variables as predictors, those being the Gini Index of household income ( $\beta=$ $0.365 ; t=2.355 ; p=0.027)$, household overcrowding $(\beta=0.353) ; t$ 
$=2.289 ; p=0.032)$ and the lethality rate $(\beta=-0.489 ; t=-3.630 ; p$ $=0.001)$ generating a model with better adjusted $\mathrm{R} 2$ and better level of statistical significance $[F(3.23)=111.387 ; p<0.001 ; R 2$ $=0.598$. In this model, $59.8 \%$ of the variation in incidence can be explained by independent variables. It was not identified any dependency on residuals or multicollinearity.

Regarding the dependent variable "mortality", the final model also included the independent variables Gini Index $(\beta=0.407$; $t=2.567 ; p=0.017)$ and overcrowding $(\beta=0.352 ; t=2.236 ; p=$ $0.017)$; and lethality rate $(\beta=0.351 ; t=2.565 ; p=0.035)$. This way, it was generated a model with adjusted $\mathrm{R} 2$ and better statistical significance level $[F(3.23)=10.528 ; p<0.001 ; R 2=0.579]$. With this model, it is suggested that $57.9 \%$ of the mortality variation can be explained by these variables. It was not identified any dependency on residuals or multicollinearity.

\section{DISCUSSION}

Incidence and mortality rates were quite distinct among the Brazilian FUs, showing heterogeneity in the country's evolution of the pandemic. The incidence rates presented a negative correlation with the pandemic time, which indicates that the spread of SARSCoV-2 was different in the FUs. The positive correlation between the time of the pandemic, the GDP per capita, and variables of the system structure, associated with the negative correlation with variables related to inadequate housing conditions and a higher percentage of people without education, suggests that the pandemic started in FU with better socioeconomic conditions and expanded to more vulnerable areas.

The association of the variable Gini Index of household income with the incidence found in the regression model shows that states with higher inequality in income distribution presented greater transmission of SARS-CoV-2. One of the probable justifications for this association would be the difficulty of excluded and economically vulnerable sectors to adhere to the social distancing measures implemented by states and municipalities, due to the need to continue their labor activities to guarantee subsistence ${ }^{(22-23)}$. These findings are in line with an ecological study conducted in the United States of America (USA) that points out a higher percentage of COVID-19 cases in areas with lower income and higher levels of poverty ${ }^{(23)}$.

Higher incidence rates were also associated with a higher proportion of people living in overcrowded households. The literature highlights that living in inadequate conditions is a risk factor for respiratory infections ${ }^{(24,27)}$. Recently, a study has shown that areas with a higher number of people per household presented higher COVID-19 infection rates and that the area population density was not a risk factor for increased transmission ${ }^{(26)}$. These results show that part of the population has limitations to the isolation of people with mild COVID-19 and the application of individual protection measures necessary to mitigate the transmission of SARS-CoV-2 at the household ${ }^{(26,28-29)}$. Besides, the population strata with lower income and more significant social vulnerability present a greater chance of residing in housing with inadequate conditions $^{(22)}$.

In the case of lethality, there was a negative correlation with the incidence rate. The lethality rates in the country were heterogeneous. A previous study demonstrated lethality variations among developed countries, even in similar pandemic times ${ }^{(4)}$. Part of the variations found may be related to differences in population profile, socioeconomic factors, or access to health care $^{(4)}$. However, a large part of this variation may be related to the heterogeneity of diagnostic tests supply and underestimating cases. In this sense, the high lethality rate found in some states would be partially related to a lower offer of tests and, consequently, to a lower identification of cases and lower incidence rates. According to the Ministry of Health's Epidemiological Bulletin, between the 10th and 34th epidemiological week, 2,307,575 tests for molecular diagnosis for COVID-19 had been performed at SUS ${ }^{(30)}$. This value is proportionally lower than most countries in the world ${ }^{(4)}$, which weakens the sizing and planning of actions to address the pandemic in Brazil.

The regression model showed that worse results in the Gini Index of household income, a higher percentage of people living in overcrowded households, a higher unemployment rate, and lethality were associated with higher mortality rates. These results suggest the importance of socioeconomic factors also in the increase in mortality by COVID 19. The association between high rates of lethality and mortality may also suggest weaknesses in access to quality care, especially in areas with lower economic development.

The study results show that there is a social determination in both incidence and mortality by COVID-19 and that there has been an expansion of the pandemic to areas of more vulnerability ${ }^{(31)}$. Analyses performed in the city of Rio de Janeiro ${ }^{(32)}$ point out a similar behavior, with a displacement of incidence to more vulnerable areas of the city and higher mortality in these regions, which corroborates the association's hypothesis between socioeconomic factors and the COVID-19 pandemic in Brazil. Another relevant aspect is that the economic crisis predicted for the moment following this first epidemic wave tends to impact especially that segment of the population, making it increasingly vulnerable to eventual new pandemics of the COVID-19.

\section{Study limitations}

This study was based on the number of cases and deaths reported by the Ministry of Health still on the rise of the pandemic curve, making it a partial analysis. Moreover, it presents limitations due to the country's low testing capacity and weaknesses in the surveillance and notification process. The aggregation of information by FU may introduce limitations by reducing the study's capability due to the low number of FU compared and not allowing the identification of intra-state variability. On the contrary, using the FU as a unit of analysis represents an advantage, since regional scope responses have been defined mostly at the state level and the fact that an essential part of the SUS management body and financing actions operates at a state scale.

\section{Contributions to the area of Nursing, Health or Public Policy}

The study reveals the importance of social determinants in the evolution of the COVID 19 pandemic in Brazil. It points out the need to consider such factors when developing public policies to confront the pandemic of COVID-19. 


\section{CONCLUSION}

Our results indicate that socioeconomic factors and social inequities influenced the dissemination and mortality of COVID-19 in Brazil. Therefore, we suggest that the coping strategies contemplate intersectoral actions, aiming at guaranteeing sanitary and economic conditions so that vulnerable populations can carry out the recommended prevention actions. Another aspect to consider is expanding public investment in health and strengthening health networks in vulnerable areas, improving the physical structure, expanding the number of health teams, and ensuring working conditions.

\section{ACKNOWLEDGMENT}

Acknowledgement: we acknowledgment the population and the researchers for their efforts to face the epidemic and health professionals, especially nursing professionals, who work on the front line in assisting people affected by COVID-19.

\section{REFERENCES}

1. Amirian ES. Potential fecal transmission of SARS-CoV-2: current evidence and implications for public health. Int J Infect Dis. 2020;95:363-70. doi: $10.1016 /$ j.jijid.2020.04.057

2. Wu JT, Leung K, Leung GM. Nowcasting and forecasting the potential domestic and international spread of the 2019-nCoV outbreak originating in Wuhan China: a modeling study. Lancet. 2020;395(10225):689-97. doi: 10.1016/S0140-6736(20)30260-9

3. Sanches S, Lin YT, Xu C, Romero-Severson E, Hengartner N, Ke R. High contagiousness and rapid spread of severe acute respiratory syndrome coronavirus 2. Emerg Infect Dis. 2020;26(7):1470-77. doi: 10.3201/eid2607.200282

4. Figueiredo AM, Daponte A, Figueiredo DCMM, Gil-Garcia E, Kalache A, Letalidad del COVID-19: ausencia de patron epidemiológico. Gac Sanit [Internet]. 2020 [cited 2020 Jun 15]. doi: 10.1016/j.gaceta.2020.04.001

5. Bedford J, Enria D, Giesecke J. COVID-19: towards controlling of a pandemic. Lancet. 2020;395(10229):1015-18. doi: 10.1016/ S0140-6736(20)30673-5

6. Tobias A. Evaluation of the lockdowns for the SARS-CoV-2 epidemic in Italy and Spain after one month follow up. Sci Total Environ. 2020;725(10). doi: 10.1016/j.scitotenv.2020.138539

7. Khalatbari-Soltani S, Cumming RG, Delpierre C, Kelly-Irving M. Importance of collecting data on socioeconomic determinants from the early stage of the COVID-19 outbreak onwards. J Epidemiol Community Health [Internet]. 2020 [cited 2020 Jun 8]. doi: 10.1136/jech-2020-214297

8. Instituto Brasileiro de Geografia e Estatística. Síntese de indicadores sociais: uma análise das condições de vida da população brasileira: 2019 [Internet]. Rio de Janeiro: IBGE; 2019. [cited 2020 May 10]. 130p. Available from: https://biblioteca.ibge.gov.br/visualizacao/livros/liv101678.pdf

9. Rache B, Rocha R, Nunes L, Spinola, P, Massuda A. Para além do custeio: necessidades de investimento em leitos de UTI no SUS sob diferentes cenários da COVID-19 [Internet]. São Paulo: Instituto de Estudos para Políticas de Saúde; 2020. (Nota Técnica, 7). [cited 2020 May 20]. Available from:https://ieps.org.br/wp-content/uploads/2020/04/IEPS-NT7.pdf

10. Silva GA, Giovanella L, Camargo Jr KR. Brazil's National Health Care System at risk for losing its universal character. Am J Public Health. 2020;110(6):811-12. doi: 10.2105/AJPH.2020.305649

11. von Elm E, Altman DG, Egger M, Pocock SJ, Gotzsche PC, Vandenbroucke JP. The Strengthening the Reporting of Observational Studies in Epidemiology (STROBE) Statement: guidelines for reporting observational studies. J Clin Epidemiol. 2008;61(4):344-9. doi: 10.1016/j. jclinepi.2007.11.008

12. Ministério da Saúde (BR). Coronavírus Brasil: Painel Coronavírus. [Internet]. Brasília: Ministério da Saúde; 2020 [cited 2020 Aug 24 ]. Available from: https://covid.saude.gov.br/

13. Instituto Brasileiro de Geografia e Estatística. População Residente. Estimativas para o TCU - Brasil. [Internet]. 2019 [cited 2020 May 10]. Available from: http://tabnet.datasus.gov.br/cgi/tabcgi.exe?ibge/cnv/poptuf.def

14. Ministério da Saúde (BR). Vigitel Brasil 2019: vigilância de fatores de risco e proteção para doenças crônicas por inquérito telefônico: estimativas sobre frequência e distribuição sociodemográfica de fatores de risco e proteção para doenças crônicas nas capitais dos 26 estados brasileiros e no Distrito Federal em 2019. [Internet]. Brasília: Ministério da Saúde; 2020 [cited 2020 May 10]. 137p. Available from: https://portalarquivos.saude.gov.br/images/pdf/2020/April/27/vigitel-brasil-2019-vigilancia-fatores-risco.pdf

15. Richardson S, Hirsch JS, Narasimhan M, Crawford JM, McGinn T, Davidson KW, et al. Presenting Characteristics, Comorbidities, and Outcomes Among 5700 Patients Hospitalized With COVID-19 in the New York City Area. JAMA. 2020;323(20):2052-59. doi:10.1001/jama.2020.6775.

16. Zhou F, Yu T, Du R, Fan G, Liu Y, Liu Z, et al. Clinical course and risk factors for mortality of adult inpatients with COVID-19 in Wuhan, China: a retrospective cohort study. Lancet. 2020;395(10229):1054-62. doi: 10.1016/S0140-6736(20)30566-3

17. Instituto Brasileiro de Geografia e Estatística. Sistema IBGE de Recuperação Automática - SIDRA. Pesquisa Nacional por Amostra de Domicílios Contínua trimestral. Tabela 5918 - População, por grupos de idade[Internet]. 2019 [cited 2020 May 10]. Available from: https:// sidra.ibge.gov.br/tabela/5918

18. Ministério da Saúde (BR). DATASUS. Cadastro Nacional de Estabelecimentos de Saúde (CNES). Recursos Humanos - Profissionais - Indivíduos - segundo CBO 2002, Brasil [Internet] 2020 [cited 2020 May 10]. Available from: http://tabnet.datasus.gov.br/cgi/tabcgi.exe?cnes/cnv/ prid02br.def 
19. Ministério da Saúde (BR). Sala de Apoio à Gestão Estratégia. Painel de leitos e insumos [Internet]. 2020 [cited 2020 May 10]. Available from: https://covid-insumos.saude.gov.br/paineis/insumos/painel_leitos.php

20. Instituto Brasileiro de Geografia e Estatística. Síntese de indicadores sociais: 2018: tabulações especiais sobre as condições de vida da população brasileira[Internet]. 2018 [cited 2020 May 10]. Available from: https://www.ibge.gov.br/estatisticas/multidominio/condicoes-devida-desigualdade-e-pobreza/9221-sintese-de-indicadores-sociais.html?edicao=27611\&t=sobre

21. Instituto Brasileiro de Geografia e Estatística. Sistema IBGE de Recuperação Automática (SIDRA). Produto interno bruto a preços correntes, impostos, líquidos de subsídios, sobre produtos a preços correntes e valor adicionado bruto a preços correntes total e por atividade econômica, e respectivas participações [Internet]. 2017 [cited 2020 May 10]. Available from: https://sidra.ibge.gov.br/tabela/5938

22. Blumenshine P, Reingold A, Egerter S, Mockenhaupt R, Braveman P, Marks J. Pandemic influenza planning in the United States from a health disparities perspective. Emerg Infect Dis. 2008;14(5):709-15. doi: 10.3201/eid1405.071301

23. Hawkins D. Social Determinants of COVID-19 in Massachusetts, United States: an Ecological Study. J Prev Med Public Health. 2020;53(4):220227. doi: $10.3961 / j p m p h .20 .256$

24. Fonseca W, Kirkwood BR, Victora CG, Fuchs SR, Flores JA, Misago C. Risk factors for childhood pneumonia among the urban poor in Fortaleza, Brazil: a case-control study. Bull World Health Organ. 1996;74:199-208. Available from: https://www.ncbi.nlm.nih.gov/pmc/ articles/PMC2486894/pdf/bullwho00400-0081.pdf

25. Krieger J, Higgins DL. Housing and Health: time again for public health action. Am J Public Health. 2002:92(5):758-68. doi: 10.2105/ AJPH.92.5.758

26. Maroko AR, Nash D, Pavilonis BT. COVID-19 and Inequity: a comparative spatial analysis of New York City and Chicago hot spots. J Urban Health. 2020;97(4):461-70. doi: 10.1007/s11524-020-00468-0

27. Rozenfeld Y, Beam J, Maier H. A model of disparities: risk factors associated with COVID-19 infection. Int J Equity Health. 2020;19(1):126. doi: $10.1186 / \mathrm{s} 12939-020-01242-z$

28. Smith JA, Judd J. COVID-19: vulnerability and the power of privilege in a pandemic. Health Promot J Austr. 2020;31(2):158-60. doi: 10.1002/ hpja.333

29. Bambra C, Riordan R, Ford J, Matthews F. The COVID-19 pandemic and health inequalities. J Epidemiol Community Health. 2020. doi: 10.1136/jech-2020-214401

30. Ministério da Saúde (BR). Secretaria de Vigilância em Saúde. Boletim Epidemiológico Especial - 28 Semana epidemiológica 34 [Internet]. Brasília: Ministério da Saúde; 2020 [cited 2020 Aug 24]. 65p. Available from: https://saude.gov.br/images/pdf/2020/August/27/Boletimepidemiologico-COVID-28-FINAL-COE.pdf

31. Souza WM, Buss LF, Candido DS, Carrera JP, Li S, et al. Epidemiological and clinical characteristics of the early phase of the COVID-19 epidemic in Brazil. medRxiv. [Internet]. 2020 [cited 2020 May 20]. doi: 10.1101/2020.04.25.20077396

32. Instituto de Pesquisa Econômica Aplicada (BR). Aspectos socioeconômicos da Covid-19: o que dizem os dados do Município do Rio de Janeiro? [Internet]. Brasília: Instituto de Pesquisa Econômica Aplicada (Ipea); 2020 (Nota Técnica, 72). [cited 2020 Aug 28]. Available from: https://www.ipea.gov.br/portal/images/stories/PDFs/nota_tecnica/200731_nt_diset_n_72.pdf 